\title{
Gamma $(\gamma)$ tocopherol upregulates peroxisome proliferator activated receptor (PPAR) gamma $(\gamma)$ expression in SW 480 human colon cancer cell lines
}

\author{
Sharon E Campbell ${ }^{1}$, William L Stone ${ }^{2}$, Sarah G Whaley ${ }^{1}$, Min Qui² and \\ Koyamangalath Krishnan*1
}

Address: ${ }^{1}$ Division of Hematology-Oncology, Department of Internal Medicine, East Tennessee State University and James H. Quillen VA Medical Center, Johnson City, TN, USA 37614 and ${ }^{2}$ Department of Pediatrics, East Tennessee State University and James H. Quillen VA Medical Center, Johnson City, TN, USA 37614

Email: Sharon E Campbell - campbese@etsu.edu; William L Stone - stone@etsu.edu; Sarah G Whaley - whaleys@etsu.edu; Min Qui - qui@etsu.edu; Koyamangalath Krishnan* - krishnak@etsu.edu

* Corresponding author

Published: 0I October 2003

BMC Cancer 2003, 3:25
Received: 09 July 2003

Accepted: 0I October 2003

This article is available from: http://www.biomedcentral.com/I47/-2407/3/25

(C) 2003 Campbell et al; licensee BioMed Central Ltd. This is an Open Access article: verbatim copying and redistribution of this article are permitted in all media for any purpose, provided this notice is preserved along with the article's original URL.

\begin{abstract}
Background: Tocopherols are lipid soluble antioxidants that exist as eight structurally different isoforms. The intake of $\gamma$-tocopherol is higher than $\alpha$-tocopherol in the average US diet. The clinical results of the effects of vitamin $\mathrm{E}$ as a cancer preventive agent have been inconsistent. All published clinical trials with vitamin $\mathrm{E}$ have used $\alpha$-tocopherol. Recent epidemiological, experimental and molecular studies suggest that $\gamma$-tocopherol may be a more potent chemopreventive form of vitamin $\mathrm{E}$ compared to the more-studied $\alpha$-tocopherol. $\gamma$-Tocopherol exhibits differences in its ability to detoxify nitrogen dioxide, growth inhibitory effects on selected cancer cell lines, inhibition of neoplastic transformation in embryonic fibroblasts, and inhibition of cyclooxygenase-2 (COX-2) activity in macrophages and epithelial cells. Peroxisome proliferator activator receptor $\gamma$ (PPAR $\gamma$ ) is a promising molecular target for colon cancer prevention. Upregulation of PPAR $\gamma$ activity is anticarcinogenic through its effects on downstream genes that affect cellular proliferation and apoptosis. The thiazolidine class of drugs are powerful PPAR $\gamma$ ligands. Vitamin E has structural similarity to the thiazolidine, troglitazone. In this investigation, we tested the effects of both $\alpha$ and $\gamma$ tocopherol on the expression of PPAR $\gamma$ mRNA and protein in SW 480 colon cancer cell lines. We also measured the intracellular concentrations of vitamin E in SW 480 colon cancer cell lines.

Results: We have discovered that the $\alpha$ and $\gamma$ isoforms of vitamin E upregulate PPAR $\gamma$ mRNA and protein expression in the SW480 colon cancer cell lines. $\gamma$-Tocopherol is a better modulator of PPAR $\gamma$ expression than $\alpha$-tocopherol at the concentrations tested. Intracellular concentrations increased as the vitamin $E$ concentration added to the media was increased. Further, $\gamma$-tocopheroltreated cells have higher intracellular tocopherol concentrations than those treated with the same concentrations of $\alpha$-tocopherol.
\end{abstract}

Conclusion: Our data suggest that both $\alpha$ and $\gamma$ tocopherol can upregulate the expression of PPAR $\gamma$ which is considered an important molecular target for colon cancer chemoprevention. We show that the expression of PPAR $\gamma$ mRNA and protein are increased and these effects are more pronounced with $\gamma$-tocopherol. $\gamma$-Tocopherol's ability to upregulate PPAR $\gamma$ expression and achieve higher intracellular concentrations in the colonic tissue may be relevant to colon cancer 
prevention. We also show that the intracellular concentrations of $\gamma$-tocopherol are several fold higher than $\alpha$-tocopherol. Further work on other colon cancer cell lines are required to quantitate differences in the ability of these forms of vitamin $E$ to induce apoptosis, suppress cell proliferation and act as PPAR ligands as well as determine their effects in conjunction with other chemopreventive agents. Upregulation of PPAR $\gamma$ by the tocopherols and in particular by $\gamma$ tocopherol may have relevance not only to cancer prevention but also to the management of inflammatory and cardiovascular disorders.

\section{Background}

Vitamin $\mathrm{E}$ is a generic term that describes a group of lipidsoluble chain breaking antioxidants that exist in nature as eight structurally related forms; four tocopherol and four tocotrienol $(\alpha, \beta, \delta$, and $\gamma)$ isoforms. The isoform found in highest concentration in serum and dietary supplements is $\alpha$-tocopherol. However, the primary form in the typical American diet is $\gamma$-tocopherol, which is present at $2-4$ times higher concentrations than $\alpha$-tocopherol [1]. Recent experimental and epidemiological studies suggest that $\gamma$ tocopherol may be superior to the commonly tested, $\alpha$ tocopherol, as a cancer chemopreventive [2-5].

Newly recognized properties of $\gamma$-tocopherol provide a basis for its superior cancer preventive activity. $\gamma$-Tocopherol was found to be superior to $\alpha$-tocopherol at inhibiting cell growth in vitro in human prostate cancer cells [4]. Cooney et al. found that $\gamma$-tocopherol was a much more potent inhibitor of neoplastic transformation in 3-methycholanthrene-treated $\mathrm{C} 3 \mathrm{H} / \mathrm{H} 10 \mathrm{~T} / 1 / 2$ murine fibroblasts than $\alpha$-tocopherol. [5]. In a nested case-control study [2] examining the effects of tocopherols and selenium on incident prostate cancer, Helzlsouer et al. found that statistically significant protective associations for high levels of selenium and $\alpha$-tocopherol were found only when $\gamma$ tocopherol levels were high. Together, these data indicate that $\gamma$-tocopherol may be a better chemopreventive agent than $\alpha$-tocopherol. We have shown that dietary $\gamma$-tocopherol, but not $\alpha$-tocopherol, is capable of down regulating the expression of the fecal ras-p21 gene. [6] in a rat model system. $\gamma$-Tocopherol may also possess superior anticarcinogenic action through effects on cell cycle proteins and prostaglandin suppression [7]. In addition, Jiang, et al. have demonstrated that $\gamma$-tocopherol suppresses the activity of cyclooxygenase (COX-2) in (LPS)stimulated RAW264.7 macrophages [8].

Members of the nuclear receptor superfamily, peroxisome proliferator activator receptors (PPARs) are ligand-activated transcription factors that regulate gene expression by binding to DNA. PPARs bind to peroxisome proliferator responsive elements (PPREs) in the promoter region of several target genes after heterodimerization with the 9cis retinoic acid receptor X (RXR). PPARs are activated by a wide variety of structurally diverse compounds that include fatty acids, eicosanoids [9], and hypolipidemic drugs like thiazolidinediones (TZDs). TZDs (troglitazone, rosiglitazone, pioglitazone, ciglitazone) are selective ligands for PPAR $\gamma$. TZD drugs were shown to inhibit cell proliferation in adipocyte cells undergoing differentiation [10]. These drugs have been further tested in human breast, prostate, and colon cancer cells resulting in inhibition of cell proliferation [11]. There is great interest in the use of TZDs as chemopreventive agents in a variety of malignancies including liposarcomas and cancers of the breast, colon and prostate. [12-15].

PPAR $\gamma$ has an important role in colon carcinogenesis. PPAR $\gamma$ is necessary for the normal growth and differentiation of colon epithelium and may achieve this by maintaining adequate levels of $\beta$-catenin. PPAR $\gamma$ ligands have been shown to be effective chemopreventive agents in a rat model of carcinogenesis and in azoxymethaneinduced colon cancer in mice [16]. Since vitamin E possesses structural similarities to the PPAR $\gamma$ ligand, troglitazone (Figure 1), we were interested to study the effects of vitamin E isoforms on PPAR $\gamma$ expression in SW480 colon cancer cell lines. Since PPAR $\gamma$ is a recognized as an important molecular target in cancer chemoprevention strategies [17], the ability of an agent to modulate PPAR $\gamma$ would be an important observation that may have clinical implications in colon cancer chemoprevention. This study demonstrates the ability of $\gamma$-tocopherol to upregulate the mRNA and protein expression of PPAR $\gamma$ in SW480 colon cancer cell lines.

\section{Methods \\ Cell Culture}

SW480 human colon cancer cell lines were purchased from American Type Culture Collection (Rockville, MD) and grown in RPMI 1640 medium containing 10\% heatinactivated fetal bovine serum (FBS), penicillin G (100 U/ $\mathrm{mL})$, and streptomycin $(100 \mathrm{U} / \mathrm{mL})$ in a humidified atmosphere of $5 \% \mathrm{CO}_{2}$ at $37^{\circ} \mathrm{C}$. COS-7 cells (a generous gift from Jonathan Moorman, M.D., East Tennessee State University, Johnson City, TN) were also grown in Dulbecco's Modified Eagle Medium with high glucose and Lglutamine. 
A.

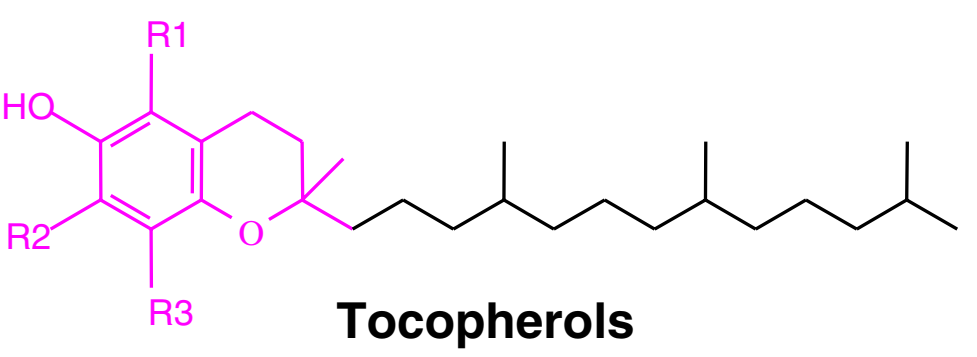

\begin{tabular}{|c|c|c|c|}
\hline Form & R1 & R2 & R3 \\
\hline$\alpha-T$ & $\mathrm{CH}_{3}$ & $\mathrm{CH}_{3}$ & $\mathrm{CH}_{3}$ \\
\hline$\beta-T$ & $\mathrm{CH}_{3}$ & $\mathbf{H}$ & $\mathrm{CH}_{3}$ \\
\hline$Y-T$ & $\mathbf{H}$ & $\mathrm{CH}_{3}$ & $\mathrm{CH}_{3}$ \\
\hline$\delta-T$ & $\mathbf{H}$ & $\mathbf{H}$ & $\mathrm{CH}_{3}$ \\
\hline
\end{tabular}

B.

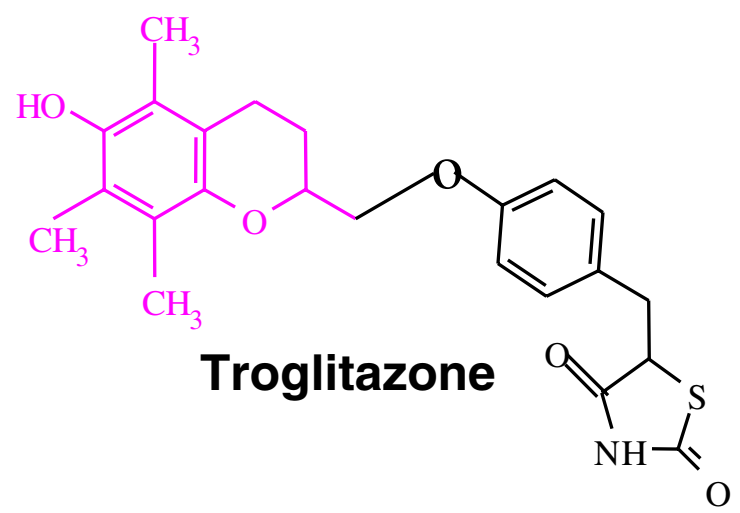

Figure I

The structure comparison of the tocopherols A) with troglitazone B). 


\section{Enrichment of Tocopherol Medium}

Prior to treatment, the cell culture medium was enriched with tocopherol by adding the appropriate amount of tocopherol to $50 \mu \mathrm{L}$ ethanol, followed by $1 \mathrm{~mL}$ of $7.5 \%$ bovine serum albumin (BSA). The BSA/tocopherol mixture was vortexed and added to $74 \mathrm{~mL}$ of culture medium supplemented with $10 \%$ fetal bovine serum (FBS) and 50 IU penicillin/streptomycin. In the vehicle-treated cells, BSA/ethanol without tocopherol was added to the culture medium.

\section{Treatment of Cells}

SW480 human colon cancer cells were seeded at a concentration of $5 \times 10^{6}$ in $100 \times 20 \mathrm{~mm}$ plates 24 hours before treatment with either $5 \mu \mathrm{M}$ or $10 \mu \mathrm{M} \alpha$-tocopherol, $\gamma$ tocopherol, vehicle (BSA + ethanol) or $100 \mu \mathrm{M}$ troglitazone (positive control) for 24 hours for mRNA expression or 48 hours for protein expression.

\section{Quantitative PCR}

Total RNA was extracted from the cells using the RNAzol B isolation kit (Tel-Test, Inc., Friendswood, TX) and quantified using an Eppendorf BioPhotometer 6131. mRNA levels of each PPAR were measured by reverse transcriptase-polymerase chain reaction (rt-PCR) using total RNA isolated from the SW480 cells and the Gene Amp kit (Perkin Elmer, Boston MA). Toaccurately quantify the cDNA from the RNA aquantitative polymerase chain reaction (QPCR) system was used. The primer pair used to amplify PPAR $\gamma$ was upper 5' AAG CCC TTC ACT ACT GTT GAC T 3' and lower 5' CAG GCT CCA CTT TGA TTG 3'. The PCR system useda fluorescent dye (SYBR Green). QPCR optimization was performed using PPAR $\gamma$ plasmid clones. Once optimized, cDNA standard curves were prepared using the PPAR $\gamma$ plasmids to calibrate PPAR $\gamma$. Assayswere performed in triplicate with negativecontrols (no reverse transcriptase) and blank reactions to assure thespecificity of the reactions. To verify that the correct sequence was amplified, the cloned and uncloned products were sequenced by the Molecular Core Facility (James H. Quillen College of Medicine, Johnson City, TN). The sequence obtained matched the proposed product with $100 \%$ accuracy.

\section{Western Blot Analysis}

Nuclear proteins were extracted from SW480 cells by a method previously described with modifications [18]. SW480 cells were harvested with trypsin-EDTA from 100 $\times 20 \mathrm{~mm}$ plates at $\sim 5.0 \times 10^{6}$ cells per plate and pelleted by centrifugation. The cell pellets were rinsed three times with phosphate buffered saline $(138 \mathrm{mM} \mathrm{NaCl} ; 2.7 \mathrm{mM}$ $\mathrm{KCl} ; 1.5 \mathrm{mM} \mathrm{KH}_{2} \mathrm{PO}_{4} ; 10 \mathrm{mM} \mathrm{NaH}_{2} \mathrm{PO}_{4}$, $\mathrm{pH}$ 7.5) PBS. To the rinsed cell pellet $100 \mathrm{~mL}$ of ice cold hypotonic buffer was added containing $10 \mathrm{mM}$ HEPES pH 7.9, $10 \mathrm{mM} \mathrm{KCl}$, $0.1 \mathrm{mM}$ EDTA, $0.1 \mathrm{mM}$ EGTA, $1 \mathrm{mM}$ dithiothreitol (DTT),
$0.5 \mathrm{mM}$ phenylmethylsulfonyl fluoride (PMSF), $1 \mathrm{mM}$ aprotinin, $1 \mathrm{mM}$ pepstatin, $14 \mathrm{mM}$ leupeptin, $50 \mathrm{mM}$ $\mathrm{NaF}, 30 \mathrm{mM}$ b-glycerophosphate, $1 \mathrm{mM} \mathrm{Na}_{3} \mathrm{VO}_{4}$, and 20 $\mathrm{mM}$ p-nitrophenyl phosphate. Cells were incubated on ice for 30 minutes and vortexed after the addition of 6.25 $\mathrm{mL}$ of $10 \%$ Nonidet P-40. After 2 minutes of centrifugation at $30,000 \times \mathrm{g}$, supernatants were kept at $-80^{\circ} \mathrm{C}$ while the pellets were collected and vortexed every 20 minutes in $60 \mathrm{~mL}$ of a hypertonic salt solution containing $20 \mathrm{mM}$ HEPES pH 7.9, 0.4 M NaCl, 1 mM EDTA, 1 mM EGTA, 12 $\mathrm{mM}$ DTT, $1 \mathrm{mM}$ PMSF, $1 \mathrm{mM}$ apotinin, $1 \mathrm{mM}$ pepstatin, $14 \mathrm{mM}$ leupeptin, $50 \mathrm{mM} \mathrm{NaF}, 30 \mathrm{mM}$-glycerophosphate, $1 \mathrm{mM} \mathrm{Na} \mathrm{VO}_{4}$, and $20 \mathrm{mM}$ p-nitrophenyl phosphate. The nuclear and cytosolic proteins were quantified by the BCA protein assay (Pierce, Rockford, IL, USA). 50 $\mu \mathrm{g}$ protein was subjected to electrophoresis in a $10 \%$ polyacrylamide ready gel in Tris HCl buffer (BioRad, Hercules, CA). The gel was blotted to a nylon membrane using a Protean II electroblotter at $100 \mathrm{~V}$ for 1 hour. The membrane was blocked with $10 \%$ milk and co-incubated with the primary antibodies to PPAR $\gamma$ and $\beta$-actin conjugated with a FITC label in 5\% milk (Santa Cruz Biotechnology, Santa Cruz, CA).

For blots using whole cell lysates, the cells were lysed in cell lysis buffer (50 mM Tris $\mathrm{HCl}, \mathrm{pH} 7.5,150 \mathrm{mM} \mathrm{NaCl}$, $1 \mathrm{mM}$ EDTA, $1 \%$ Triton X-100 and $0.5 \%$ SDS). The protein in each lysate was quantified using the BCA assay (Pierce, Rockford, IL, USA). $100 \mu \mathrm{g}$ protein from whole cell lysate was subjected to electrophoresis in a $10 \%$ polyacrylamide ready gel in Tris $\mathrm{HCl}$ buffer (BioRad, Hercules, CA) followed by blotting as previously described.

\section{Transient Transfection of COS 7 cells with pCMX-PPAR $\gamma$ expression vector}

COS-7 cells at a density of $5 \times 10^{6}$ cells were transiently transfected with $24 \mu \mathrm{g}$ pCMX-mPPAR $\gamma$ expression vector (a generous gift from Doug Thweke, PhD, East Tennessee State University, Johnson City, TN 37604) by Lipofectamine 2000 reagent (Invitrogen, Carlsbad, CA) according to the manufacturers directions. After a 24-hour incubation period, the cells were lysed and proteins were isolated (as previously described) for use as positive control for the Western Blot analysis.

\section{HPLC Analysis}

Media from treated SW480 cells were collected in $400 \mu \mathrm{L}$ aliquots in glass vials for HPLC analysis. The adherent cells were washed three times with phosphate buffered saline (138 mM NaCl; $2.7 \mathrm{mM} \mathrm{KCl} ; 1.5 \mathrm{mM} \mathrm{KH}_{2} \mathrm{PO}_{4} ; 10$ $\mathrm{mM} \mathrm{NaH} \mathrm{PO}_{4}, \mathrm{pH} 7.5$ ), then overlaid with $400 \mu \mathrm{L}$ of Lysis Buffer (1\% Triton X-100, pH 7.5, 20 mM HEPES buffer with $0.1 \mathrm{mM}$ EDTA), scraped and collected into a glass vial for tocopherol analysis by HPLC. The media sample or cell sample was mixed with $1.0 \mathrm{~mL}$ ethanol and 
$1.0 \mathrm{~mL}$ hexane. After vortexing the mixture was centrifuged at $1020 \times \mathrm{g}$ for 5 minutes and a $400 \mu \mathrm{L}$ sample of the upper layer was removed, dried under $\mathrm{N}_{2}$ and taken up with $100 \mu \mathrm{L}$ of mobile phase. The mobile phase was methanol: water (90:10) containing $3 \mathrm{fM}$ EDTA and 20 $\mathrm{mM}$ ammonium acetate, $\mathrm{pH}$ 4.4. The tocopherol content was measured using a HPLC equipped with a Coulochem II Electrochemical Detector, a ESA model 580 solvent delivery module, a catecholamine HR- 80 column $(\mathrm{C} 18,3$ mm, $8 \mathrm{~cm}$ ), a Model 5011 Analytical Cell, a Model 5020 guard cell (Chelmsford, MA), a PE Nelson 900 Series interface with PE Nelson Turbochrom V4 software (Perkin Elmer, San Jose, CA). The flow rate was adjusted to 1.5 $\mathrm{mL} / \mathrm{min}$ with $\mathrm{E} 1=-600 \mathrm{mV}$ (the first analytical cell potential), E2 $=400 \mathrm{mV}$ (the second analytical cell potential), and $\mathrm{E} 3=300 \mathrm{mV}$ (the conditioning cell potential). The response factors of tocopherols relative to tocol were determined in triplicate. The concentrations of $\alpha$-tocopherol and $\gamma$-tocopherol were measured using a Spectronic Genesys 5 spectrophotometer and published extinction coefficients [19]

\section{Results \\ PPAR $\gamma$ mRNA expression}

To determine whether $\alpha$-tocopherol or $\gamma$-tocopherol could upregulate PPAR $\gamma$ mRNA expression, total RNA was isolated from SW480 colon cancer cells at 24 hours after treatment with $\alpha$-tocopherol, $\gamma$-tocopherol ( $5 \mu \mathrm{M}$ or 10 $\mu \mathrm{M}$ ) or $100 \mu \mathrm{M}$ troglitazone (positive control). The total RNA was reverse transcribed to cDNA. Changes in the mRNA expression were quantified using the cDNA and QPCR reaction with SYBR green. Figure 2a shows the differences in mRNA expression as a result of treatment with $5 \mu \mathrm{M}$ tocopherols compared to the vehicle and troglitazone-treated cells. Figure $2 \mathrm{~b}$ represents the $5 \mu \mathrm{M}$ data normalized to the vehicle treatment and expressed as a fold increase in PPAR $\gamma$ copy number. Figure $2 \mathrm{c}$ is an average of three treatments at $5 \mu \mathrm{M}$ normalized to the vehicle treatment and expressed as a fold increase in PPAR $\gamma$ copy number. Figure $3 a$ shows the differences in mRNA expression as a result of treatment with $10 \mu \mathrm{M}$ tocopherols compared to the vehicle and troglitazone-treated cells. Figure $3 \mathrm{~b}$ represents the $10 \mu \mathrm{M}$ data normalized to the vehicle treatment and expressed as a fold increase in PPAR $\gamma$ copy number. Figure $3 \mathrm{c}$ is an average of three treatments at 10 $\mu \mathrm{M}$ normalized to the vehicle treatment and expressed as a fold increase in PPAR $\gamma$ copy number. The results presented here (Figures 2a,2b, 3a and $3 b$ ) are representative of three independent experiments at the stated tocopherol concentrations. The relative copy number varies from cell population to cell population. According to Gupta, [17], the highest level of receptor expression in colonic tissue occur in postmitotic cells. The data represented in figure $2 \mathrm{a}$ and figure $3 \mathrm{a}$ are representative of two different cell populations seeded and treated on different days. For this reason we have averaged the fold increase data at each concentration (Figures $2 \mathrm{~b}$ and $3 \mathrm{~b}$ ). The error bars in figure $2 \mathrm{c}$ and $3 \mathrm{c}$ are the Standard Error of the Mean for the three experiments. HCT-116 cells have been tested at each of these tocopherol concentrations with similar results (data not shown). $\alpha$-Tocopherol and $\gamma$-tocopherol can upregulate mRNA expression when compared to the vehicle. However, at both concentrations tested, $\gamma$-tocopherol was more efficient at upregulation of PPAR $\gamma$ mRNA.

\section{Protein expression of PPAR $\gamma$}

To determine whether there was a concomitant increase in PPAR $\gamma$ protein expression, Western blot analysis was performed at 24 or 48 hours after treatment with $5 \mu \mathrm{M}$ or 10 $\mu \mathrm{M}$ tocopherols or $100 \mu \mathrm{M}$ troglitazone. Figure 4a shows the Western Blot of the nuclear fraction of proteins extracted from SW480 cells after 24 hours of tocopherol treatment. Figure $4 \mathrm{~b}$ is a bar graph representing the densitometry of the gel shown in figure $4 \mathrm{a}$. This demonstrates that $\gamma$-tocopherol upregulates PPAR $\gamma$ protein expression in the nucleus where gene regulation occurs. The protein in the cytosolic fraction at this treatment time did not vary with respect to treatment (data not shown). Figure 5a shows the Western blot of a whole cell lysate after 48 hours of $10 \mu \mathrm{M}$ tocopherols treatment. Figure $5 \mathrm{~b}$ is a bar graph that represents the densitometry of figure 5a. $\gamma$ Tocopherol up regulates protein expression much more efficiently than does $\alpha$-tocopherol or troglitazone at a concentration of 20 times in excess.

\section{Cellular uptake of tocopherols}

To determine the amount of tocopherol taken up by the cell, an HPLC analysis of the cell lysates was performed. Table 1 shows the results of this analysis performed in triplicate for the SW480 cells. Using treatment concentrations of both 5 and $10 \mu \mathrm{M}$ for 24 hours, the SW480 cells incorporated 20 times more $\gamma$-tocopherol than $\alpha$-tocopherol. The data from the LOVO cell line is representative of one independent experiment that give similar results to the SW480 cells.

\section{Discussion and Conclusions}

$\gamma$-Tocopherol may be a better cancer chemopreventive agent based on the following evidence from the literature. $\gamma$-Tocopherol inhibits the activity of COX-2 in lipopolysaccharide (LPS)-stimulated RAW264.7 macrophages and IL-1 $\beta$-treated A549 human epithelial cells $[8,20]$. Inhibition of COX-2 results in a block in tumor growth $[21,22]$. In addition, inhibition of COX-2 reduces inflammation in a number of proinflammatory disorders and degenerative diseases such as rheumatoid arthritis, asthma, hepatitis and cardiovascular disease [7]. Also, $\gamma$-tocopherol is superior to $\alpha$-tocopherol for growth inhibition of prostate cancer cells [4]. Cooney et al. found that $\gamma$-tocopherol was a more potent inhibitor of neoplastic transformation in 3- 
A.

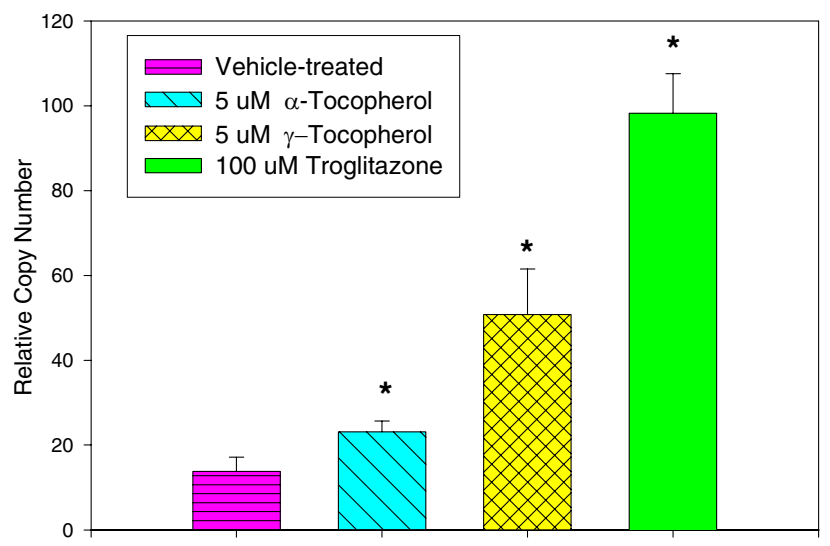

B.

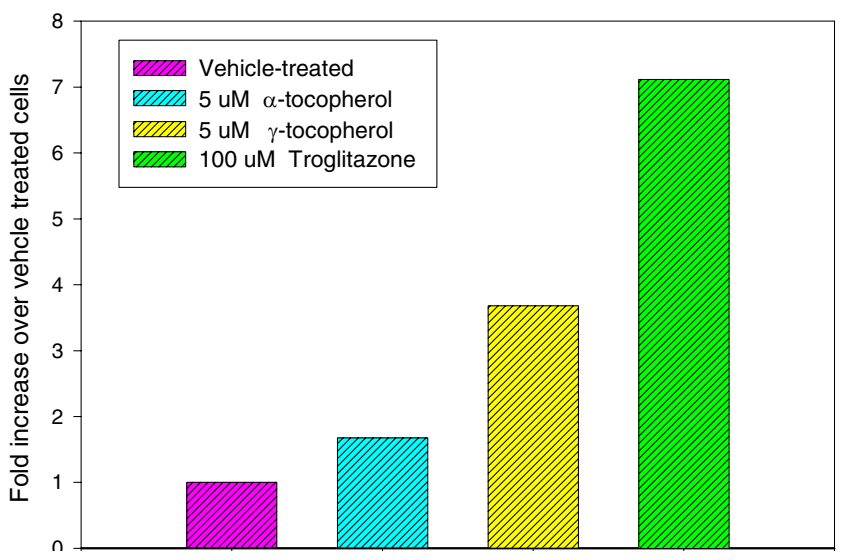

Average PPAR $\gamma$ fold increase over vehicle with 5 micromolar tocopherol treatments

c.

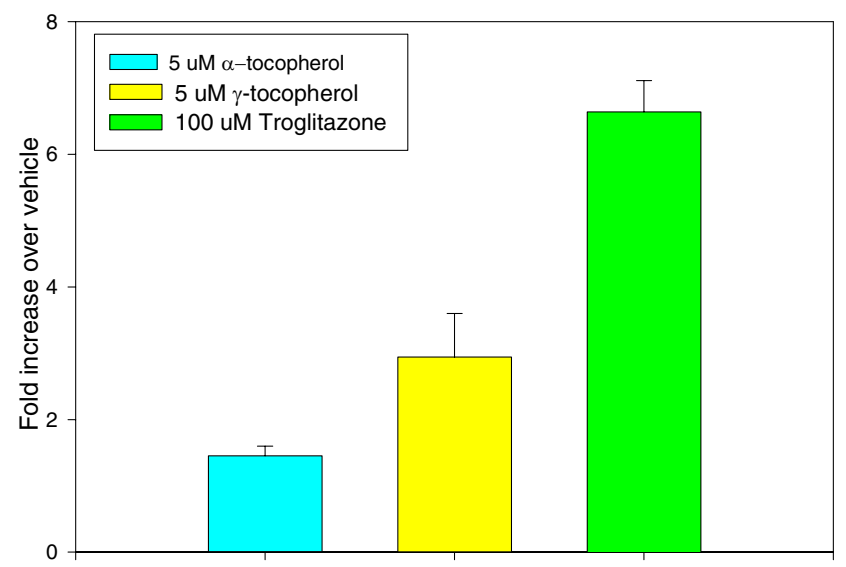

Figure 2

Tocopherol upregulation of PPAR $\gamma$ mRNA expression detected by QPCR after 24 hours of treatment with $5 \mu M$ tocopherol. A) Relative copy number of a representative QPCR AT $5 \mu \mathrm{M}$ tocopherol concentration. B) Fold increase data of the representative QPCR data shown in figure 2A. C) Average fold increase data of three independent experiments at $5 \mu M$ tocopherol concentration. * shows sample statistical difference compared to the vehicle-treated. 
A.

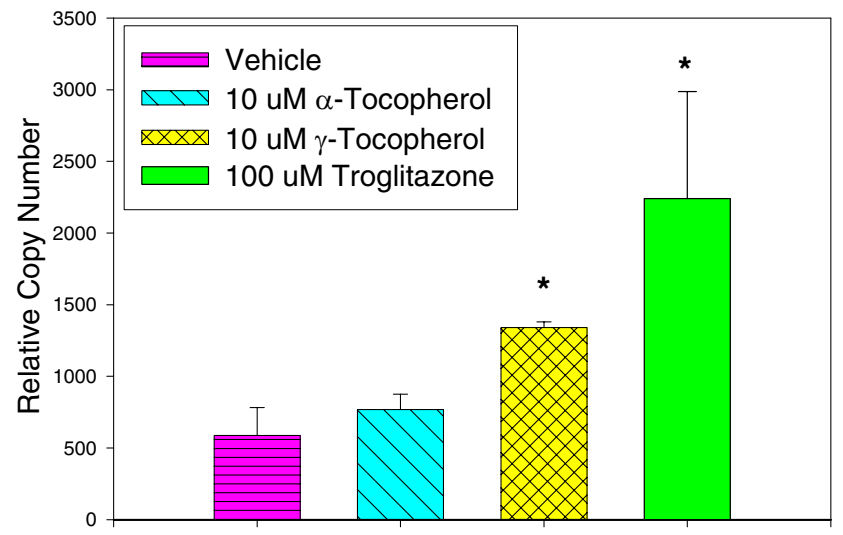

B.
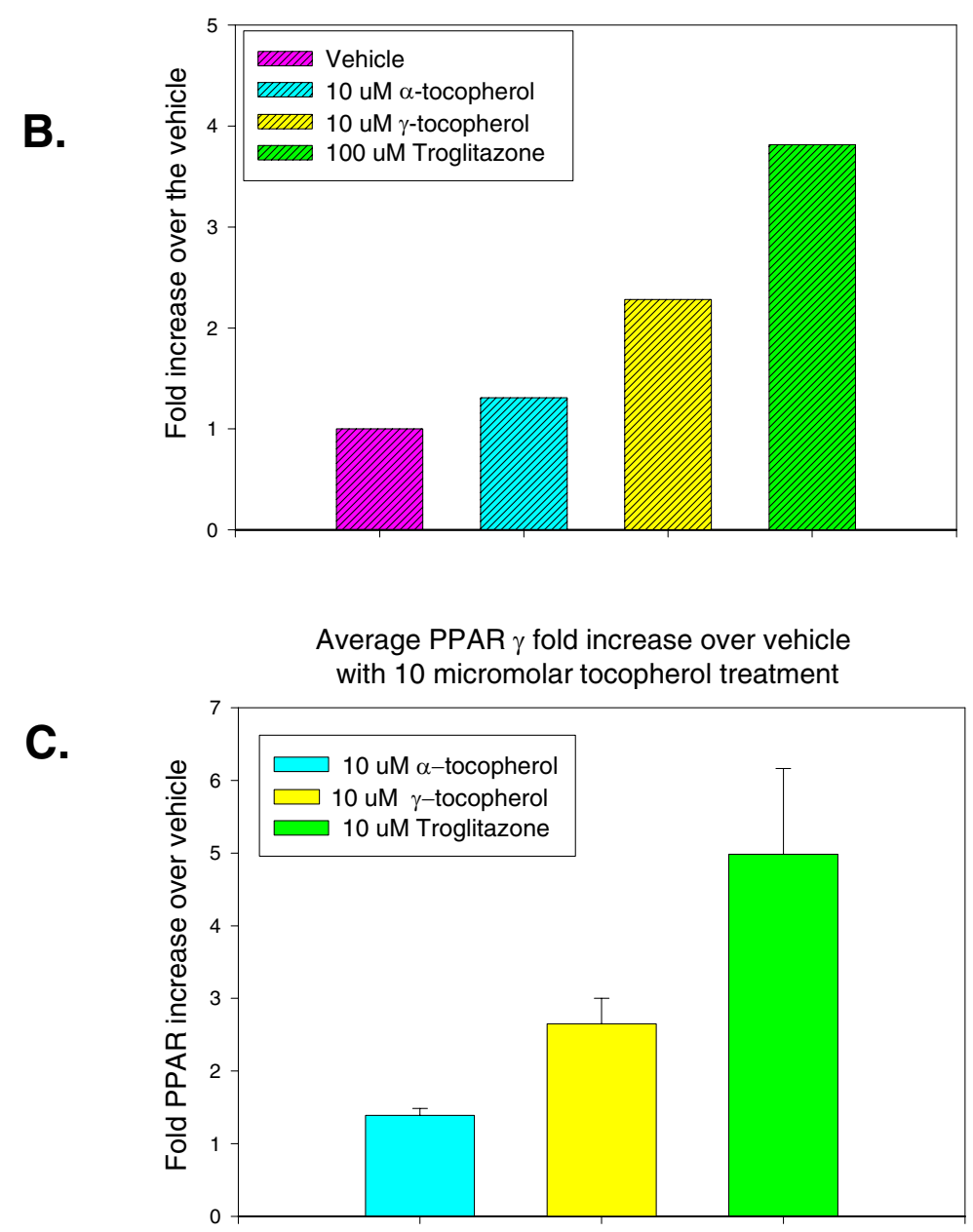

Figure 3

Tocopherol upregulation of PPAR $\gamma$ mRNA expression detected by QPCR after 24 hours of treatment with $10 \mu M$ tocopherol. A) Relative copy number of a representative QPCR AT $10 \mu \mathrm{M}$ tocopherol concentration. B) Fold increase data of the representative QPCR data shown in figure 3A. C) Average fold increase data of three independent experiments at $10 \mu M$ tocopherol concentration. * shows sample statistical difference compared to the vehicle-treated. 
A.
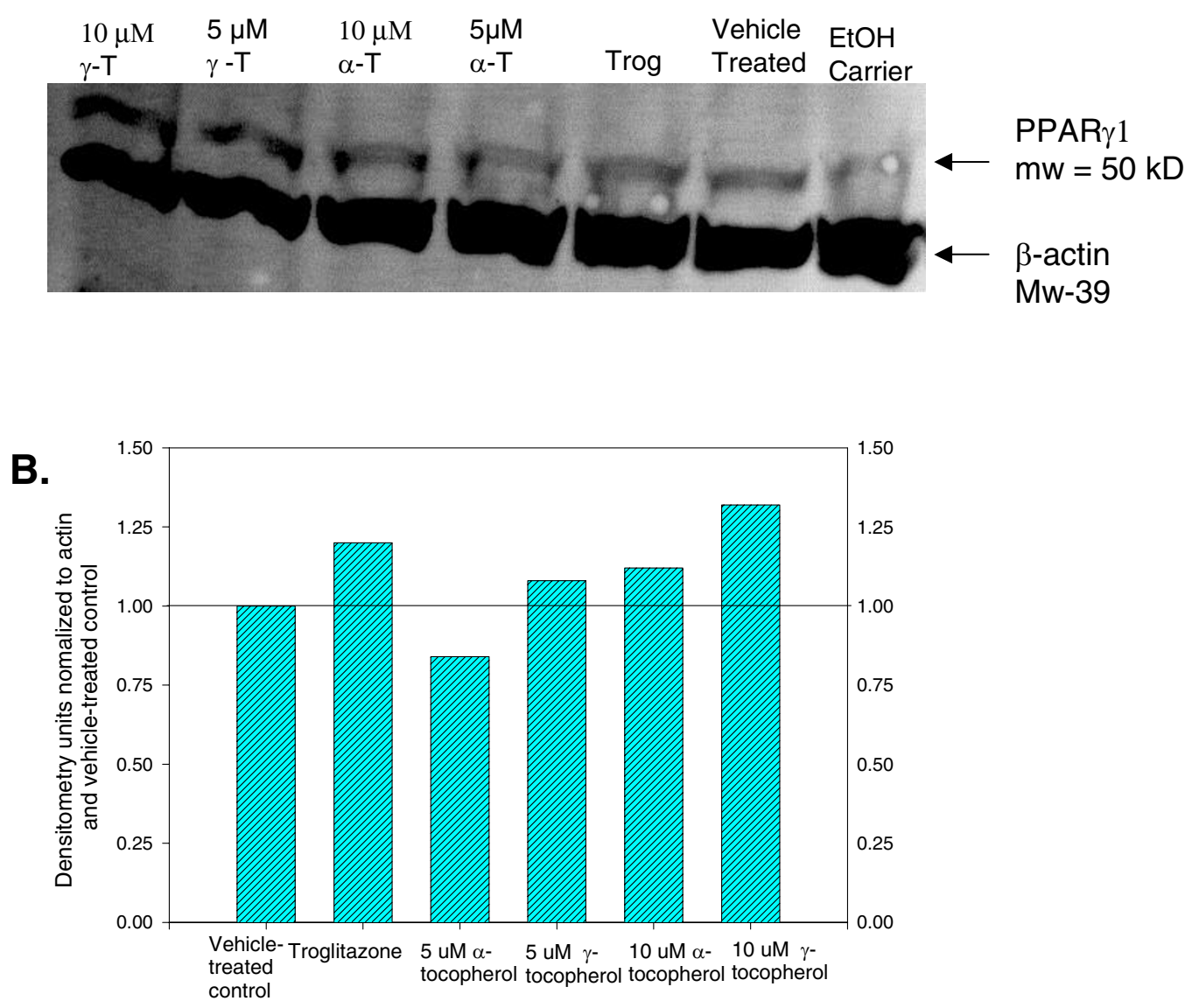

\section{Figure 4}

Tocopherol upregulation of PPAR $\gamma$ protein by Western Blot analysis of A) 24-hour tocopherol-treated SW480 nuclear extracts: lane I - I0 $\mu \mathrm{M} \gamma$-tocopherol, lane $2-5 \mu \mathrm{M} \gamma$-tocopherol lane 3-10 $\mu \mathrm{M} \alpha$-tocopherol, lane $4-5 \mu \mathrm{M} \alpha$-tocopherol, lane 5 - $100 \mu \mathrm{M}$ troglitazone, lane 6 - blank, lane 7-ethanol carrier control.B) Bar graph of densitometries for Western Blot shown in figure $4 \mathrm{~A}$.

methylcholanthrene-treated C3H/10T1/2 murine fibroblasts than $\alpha$-tocopherol [5]. Furthermore, $\gamma$-tocopherol shows a remarkable ability to reduce nitrogen dioxide to nitric oxide that is not shared with $\alpha$-tocopherol $[5,23]$. Likewise, Bittrich et al. found that $\mathrm{NO}_{2}$ can induce singlestrand DNA breaks in V79 cells that were better reduced by $\gamma$-tocopherol in comparison to other lipid soluble antioxidants [24]. Christen et al. found that peroxynitrite- induced lipid peroxidation in liposomes was more effectively inhibited by $\gamma$-tocopherol than $\alpha$-tocopherol [20] These authors also suggest that $\gamma$-tocopherol is required to effectively remove peroxynitrite-derived nitrating species. It also has recently been found that $\gamma$-tocopherol, in contrast to $\alpha$-tocopherol, can suppress the expression of rasp21 in rat colonocytes [6]. The role of ras-p21 in promoting oncogenesis has been described [25]. Gysin, et al. has 
A.

Transfected (-) Vehicle $10 \mu \mathrm{M} \quad 10 \mu \mathrm{M}$

(+) Control Control treated $\alpha-T \quad \gamma-T \quad$ Trog
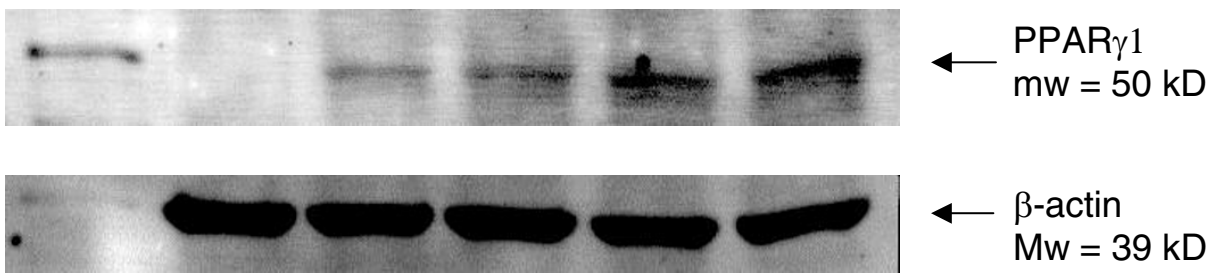

B.

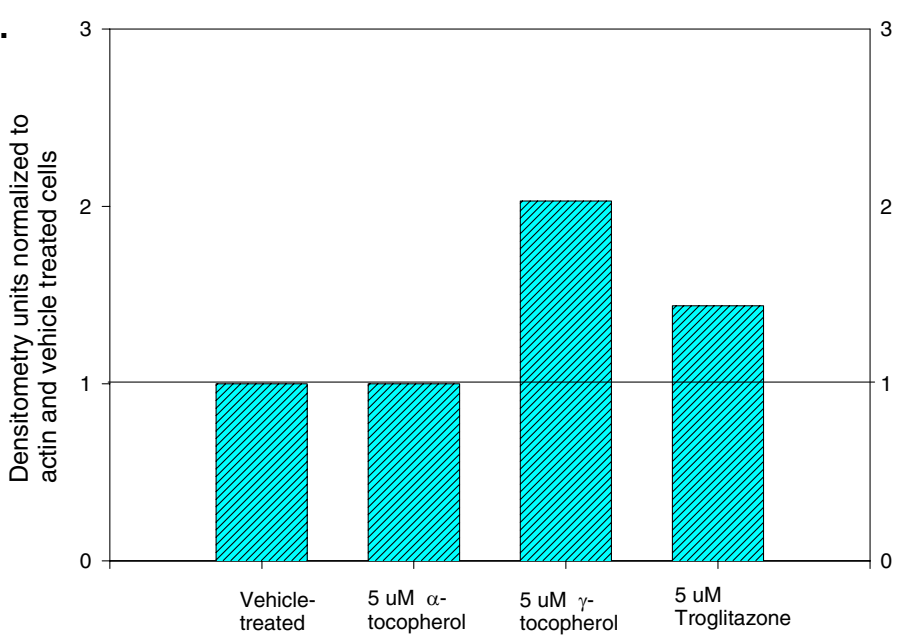

\section{Figure 5}

Tocopherol upregulation of PPAR $\gamma$ protein by Western Blot analysis of A)48-hour tocopherol-treated SW480 whole cell lysates: lane I - PPAR $\gamma$ control from transfected COS cells, lane 2 - negative control from untreated Jurkat cells, lane 3 - vehicle-treated control, lane 4 - $10 \mu \mathrm{M} \alpha$-tocopherol, lane 5 - $10 \mu \mathrm{M} \gamma$-tocopherol, lane 6 - $100 \mu \mathrm{M}$ troglitazone. B) Bar graph of densitometries for Western Blot shown in figure $5 \mathrm{~A}$.

shown that $\gamma$-tocopherol down-regulates cyclin D1 and E in cancer cell lines [26]. Recent work from Jiang, et al. shows that $\gamma$-tocopherol is superior to $\alpha$-tocopherol at decreasing proinflammatory eicosanoids and inflammation damage in rats. Several lines of evidence hence point to the superiority of $\gamma$-tocopherol in cancer prevention.
With these data in mind, we sought to determine if $\gamma$-tocopherol could modulate PPAR $\gamma$ expression in SW480 colon cancer cells better than $\alpha$-tocopherol. Neoplastic cell growth results from an imbalance between cell proliferation, apoptosis and terminal differentiation. In normal cells, activation of certain pathways lead to cellular differentiation which is accompanied by inhibition of cell proliferation. Malignant cells are uniformly characterized 
Table I: SW480 intracellular tocopherol concentrations (pmoles/well) after 24 hour treatments with 5 or $10 \mu \mathrm{M}$ tocopherols as determined by HPLC analysis. The result is an average of three trials and the Standard Error of the Mean (SEM) is reported. $\gamma$ Tocopherol incorporates into the SW 480 cells at levels up to 20 -fold that of $\alpha$-tocopherol at the same treatment concentration.

\begin{tabular}{|c|c|c|}
\hline Treatment Cell Line & Mean Tocopherol Concentration (pmole/well) $\mathbf{N}$ & Standard Error of Mean \\
\hline $5 \mu \mathrm{M} \alpha$-tocopherol & 10.20 & 4.11 \\
\hline SW -480 cells & 3 & \\
\hline $5 \mu \mathrm{M} \gamma$-tocopherol & 197.5 & 49.52 \\
\hline SW-480 cells & 3 & \\
\hline $10 \mu \mathrm{M} \alpha$-tocopherol & 17.42 & 5.81 \\
\hline SW -480 cells & 3 & \\
\hline $10 \mu \mathrm{M} \gamma$-tocopherol & 360.54 & 69.97 \\
\hline SW-480 cells & 3 & \\
\hline $5 \mu \mathrm{M} \alpha$-tocopherol & 4.10 & N/A \\
\hline LOVO cells & I & \\
\hline $5 \mu \mathrm{M} \gamma$-tocopherol & 152.50 & N/A \\
\hline LOVO cells & 1 & \\
\hline
\end{tabular}

by uncontrolled growth and inability to express the differentiated features characteristic to the tissue from which they arise. Treating cancer through the induction of cell differentiation has been an appealing concept, but development of differentiation inducing agents to treat cancer has been limited. Certain TZD drugs act as agonists for the PPARs and were shown to inhibit cell proliferation in adipocyte cells undergoing differentiation [10]. These drugs were further tested in human breast, prostate, and colon cancer cells resulting in inhibition of cell proliferation [27]. A pilot study has demonstrated that treatments of patients with solid liposarcomas with PPAR $\gamma$ agonists result in antineoplastic pro-differentiation. Further, PPAR agonists were shown to inhibit cell growth and suppress the expression of cyclin D1 and EGF-like growth factors in ras-transformed rat intestinal epithelial cells [28]. PPAR activation in non-small cell lung cancer cell lines resulted in growth arrest, irreversible loss of capacity for anchorage-independent growth, decreased activity and expression of matrix metalloproteinase 2 and modulation of multiple markers consistent with differentiation as well as the upregulation of markers consistent with a differentiated state [29]. Target genes of PPAR $\gamma$ were determined by microarray analysis through the efforts of Gupta, et al. As expected, genes regulated by PPAR $\gamma$ were those involved in lipid transport and storage such as adipophilin and liver fatty acid binding protein. However, genes that are linked to growth regulatory pathways such as regenerating gene IA, and colon epithelial cell maturation such as GOB-4 and keratin 20 were also regulated by PPAR $\gamma$ [30]. All of the above data suggest that PPAR $\gamma$ has a function to protecting cells against cellular transformation. Therefore, using PPAR $\gamma$ agonists could slow the proliferative rate, thereby slowing the progression of disease [27]. The most effective PPAR $\gamma$ agonist, troglitazone, has lost FDA approval due to liver toxicity. Finding a nutrient based
PPAR $\gamma$ agonist could prove beneficial in future chemoprevention strategies.

$\gamma$-Tocopherol may be superior to $\alpha$-tocopherol as a cancer preventive based upon recent epidemiological, experimental and molecular data. Epidemiological studies relating vitamin E to colon cancer have been inconsistent and mixed. Most studies in the past provided data regarding $\alpha$ tocopherol.

One epidemiological study has shown an emerging role for $\gamma$-tocopherol in the reduction of cancer. A nested casecontrol study in Washington County, MD [2] examining the effects of $\alpha$-tocopherol, $\gamma$-tocopherol and selenium on the incidence of prostate cancer determined that significantly protective associations for selenium and $\alpha$ tocopherol were found only when $\gamma$-tocopherol concentrations were high. A possible reason for the protective effects in the presence of high $\gamma$-tocopherol concentrations is that $\gamma$ tocopherol enhances the cellular uptake of $\alpha$ tocopherol. This was demonstrated by Gao et al. which show that uptake of $\alpha$-tocopherol is enhanced by the presence of $\gamma$-tocopherol in RAW 264.7 macrophages [31]. In an animal model graded dietary levels of RRR- $\gamma$-tocopherol induced marked increase in tissue concentrations of $\alpha$ - and $\gamma$-tocopherol in heart, liver, nervous tissue and muscle of vitamin E deficient rats [32]. These observations would suggest that the tocopherol isoforms work in concert for delivery to tissues. Our data show that $\gamma$-tocopherol accumulates in colon cancer cells at a twenty fold increase over $\alpha$-tocopherol (Table 1 ). This data in combination with that of $\mathrm{Gao}$, et al. provides an explanation as to why $\gamma$-tocopherol is better at modulation of PPAR $\gamma$ (as seen here), is superior to $\alpha$-tocopherol for growth inhibition of prostate cancer cells [4] and is a more potent inhibitor of neoplastic transformation in 3- 
methylcholanthrene-treated C3H/10T1/2 murine fibroblasts than $\alpha$-tocopherol [5]. Further evidence of this is provided by the Ingles study [3]. Ingles assayed plasma $\alpha-$ and $\gamma$-tocopherol concentrations in 332 subjects with colorectal adenomas and 363 control subjects. They found increasing plasma $\alpha$-tocopherol and decreasing $\gamma$ tocopherol levels were associated with the decreased occurrence of large ( $>$ or $=1 \mathrm{~cm})$ but not small $(<1 \mathrm{~cm})$ adenomas that were not statistically significant. They observed a stronger trend $(p=0.02)$ when the plasma $\alpha$ tocopherol: $\gamma$-tocopherol ratio had an odds ratio of 0.36 (95\% confidence interval, $0.14-0.95)$ for large adenomas. Of the quintile where protective effects were observed, $88 \%$ of the subjects reported taking $\alpha$-tocopherol supplements. The dietary intake of $\gamma$-tocopherol is at least two times that of $\alpha$-tocopherol in Western diets, nevertheless, the plasma levels of $\gamma$-tocopherol are about four times lower than $\alpha$-tocopherol. The most accepted explanation for this is the selective retention of $\alpha$-tocopherol by the $\alpha$-tocopherol transfer protein ( $\alpha$-TTP) [33]. $\alpha$-Tocopherol and $\gamma$-tocopherol compete for the binding sites on the $\alpha$-TTP with selectivity lying toward $\alpha$-tocopherol when it is available. In the Ingles study, by increasing the available $\alpha$-tocopherol through supplementation the plasma $\gamma$-tocopherol is decreased and the $\alpha$-tocopherol: $\gamma$ tocopherol plasma ratio is naturally increased with more $\alpha$-tocopherol being available for delivery to the tissues. We contend that if these subjects had relied on a diet rich in mixed tocopherols or taken a mixed tocopherol supplement, an even higher protective effect would have been seen resulting from increased $\gamma$-tocopherol in the plasma which would have enhanced the uptake of $\alpha$-tocopherol into the tissues [31]. The increased $\alpha$-tocopherol: $\gamma$-tocopherol ratio in the plasma in the Ingles study is a marker of $\alpha$-tocopherol supplementation and the selectivity of the $\alpha$-TTP but not a necessary condition for the chemopreventive effects conferred. The combined data of Gao, et al., Clement, et al. and Stone, et al. suggest that mixed tocopherol supplementation can have positive effects on both the $\alpha$-tocopherol and $\gamma$-tocopherol plasma concentrations $[31,32,34]$. We further contend that while at the time, the use of plasma concentrations may have seemed to be a good measure for tissue distribution this may need to be reconsidered for tocopherols, as $\gamma$-tocopherol has been shown to accumulate at higher concentrations in RAW 267.4 macrophages and colon cancer cell lines [31]. Further plasma concentrations of the tocopherols have been demonstrated to be influenced by other dietary factors including saturated fats [34]. Clearly more research needs to be conducted on the dietary factors that can influence $\alpha$-and $\gamma$-tocopherol uptake and depletions from the plasma before use of plasma data can be made conclusive. The higher intracellular levels of $\gamma$-tocopherol in the SW 480 cell lines have important clinical implications to human colorectal cancer chemoprevention. A higher intracellular concentration of $\gamma$-tocopherol level can contribute to more effective intracellular antioxidant and regulatory mechanisms. This in vitro observation needs to be demonstrated in Phase I human chemoprevention trials. Our data also shows that while $\gamma$-tocopherol is a better modulator of PPAR $\gamma$ expression, $\alpha$-tocopherol is also able to modulate PPAR $\gamma$ expression. Investigations are ongoing in our laboratory to determine if mixed tocopherols will have an additive or synergistic affect on the expression of PPAR $\gamma$ in colon cancer cell lines.

We have shown that PPAR $\gamma$ mRNA expression is upregulated by $\gamma$-tocopherol when compared to $\alpha$-tocopherol. In addition, we show that protein expression of PPAR $\gamma$ is modulated by the tocopherols. The fact that PPAR $\gamma$ in nuclear fraction is upregulated may be particularly important. This shows that tocopherols can modulate gene expression through PPAR $\gamma$. Troglitazone was shown to induce the expression of PPAR $\gamma$ in non-adipose tissues [35]. Davies et al. hypothesized that troglitazone binds to and activates the small amount of PPAR $\gamma$ present in non adipose cells. This complex in turn binds to cis-elements in the promoter region of the PPAR $\gamma$ gene leading to induction of transcription and protein levels $[36,37]$. This hypothesis was tested by Davies et al. using other PPAR $\gamma$ ligands such as ciglitazone, englitazone, rosiglitazone, and 15-deoxy- $\Delta^{12,14}$-prostaglandin $\mathrm{J}_{2}$ [37]. Troglitazone was the only known PPAR activator tested in this study to have an effect on the regulation of PPAR $\gamma$ expression. Vitamin E shares structural similarity to troglitazone as both molecules have a chromanol ring. The tocopherols have a phytyl side chain attached to their chromanol head, while troglitazone has a thiazolidiendione moiety (See Figure $1)$. Davies tested the ability of $\alpha$-tocopherol at high concentrations to upregulate the expression of PPAR $\gamma . \alpha$ Tocopherol was able to upregulate the expression of PPAR $\gamma$ at concentrations greater than $100 \mu \mathrm{M}$ in primary hepatocytes. We sought to determine whether lower concentrations could be used to upregulate PPAR $\gamma$ expression in colon cancer cells. We have shown that mRNA and protein of SW480 colon cancer cells are upregulated above the control with as little as $5 \mu \mathrm{M}$ and $10 \mu \mathrm{M}$ tocopherols. Higher concentrations of tocopherols are being tested, but have resulted in cell death in three colon cancer cell lines (data to be discussed in detail in a manuscript in preparation).

In summary, we have shown that vitamin E can modulate PPAR $\gamma$ expression in SW 480 colon cancer cell lines. Moreover, the upregulation of PPAR $\gamma$ by $\gamma$-tocopherol is more significant than the upregulation of PPAR $\gamma$ by $\alpha$-tocopherol perhaps due the ability of $\gamma$-tocopherol to accumulate at higher concentrations in the cell. Further work is currently being done to identify the effects of vitamin $\mathrm{E}$ isoforms in other colon cancer cell lines that have varied 
features to further understand the effects of $\gamma$ tocopherol. The upregulation of PPAR $\gamma$ by the tocopherols may have implications beyond cancer prevention since modulation of PPAR $\gamma$ can have effects on lipid metabolism, management of diabetes mellitus, inflammatory disorders and cardiovascular disease.

\section{Abbreviations \\ Cyclooxygenase COX}

Peroxisome Proliferator Activated Receptor PPAR

Peroxisome Proliferator Response Element PPRE

Retinoic Acid Receptor RXR

Thiazolidiendione TZD

Bovine Serum Albumin BSA

Fetal Bovine Serum FBS

Reverse transcriptase $\mathrm{rt}$

Phosphate Buffered Saline PBS

Ethylene-Diamine-Tetra-Acetic acid EDTA

$\mathrm{N}$-2-Hydroxyethylpiperazine-N'-2-ethanesulfonic acid HEPES

Ethylene glycol-O,O'-bis-[2-amino-ethyl]-N,N,N',N',tetra-acetic acid EGTA

\section{Dithiothreitol DTT}

Phenyl-methyl-sulfonyl-fluoride PMSF

Fluorescein isothiocyanate FITC

Bicinchoninic Acid BCA

High Performance Liquid Chromatography HPLC

Lipopolysacharide LPS

Very low density lipoproteins VLDL

$\alpha$-tocopherol transfer protein $\alpha$-TTP

quantitative polymerase chain reaction QPCR

\section{Competing Interests}

None declared.

\section{Authors' Contributions}

SC conceived the study, and participated in the study design, performed data analysis, aided in troubleshooting assays and drafted the manuscript. WS participated in the design and coordination of the delivery of the vitamin $\mathrm{E}$ isoforms to the cells and the HPLC analysis. SW carried out the PCR assays and Western Blot analyses, while QM carried out he HPLC analyses. KK conceived the study along side SC, participated in the study design and guided trouble shooting assays, and manuscript preparation. All authors read and approved the final manuscript.

\section{Acknowledgements}

We would like to thank the Cancer Research and Prevention Foundation of America postdoctoral fellowship award to Dr. Sharon Campbell. We also acknowledge funding to Dr. K. Krishnan from Ehrlmann Eagles Cancer Research Fund, Research and Development Committee of East Tennessee State University. We would also like to thank Dr. John Laffan for instruction on QPCR techniques. We would especially like to thank the reviewers whose comments have made this article stronger.

\section{References}

I. Stone WL and Papas AM: Tocopherols and the etiology of colon cancer. J Natl Cancer Inst 1997, 89: I006- I0I4.

2. Helzlsouer KJ, Huang HY, Alberg AJ, Hoffman S, Burke A and Norkus EP et al:: Association between alpha-tocopherol, gammatocopherol, selenium, and subsequent prostate cancer. J Natl Cancer Inst 2000, 92:2018-2022.

3. Ingles SA, Bird CL, Shikany JM, FrankI HD, Lee ER and Haile RW: Plasma tocopherol and prevalence of colorectal adenomas in a multiethnic population. Cancer Res 1998, 58:66I-666.

4. Moyad MA, Brumfield SK and Pienta KJ: Vitamin E, alpha- and gamma-tocopherol, and prostate cancer. Semin Urol Oncol 1999, 17:85-90.

5. Cooney RV, Franke AA, Harwood PJ, Hatch-Pigott V, Custer LJ and Mordan LJ: Gamma-tocopherol detoxification of nitrogen dioxide: superiority to alpha-tocopherol. Proc Natl Acad Sci U S A 1993, 90: 177I-1775.

6. Stone WL, Papas AM, LeClair IO, Qui M and Ponder T: The influence of dietary iron and tocopherols on oxidative stress and ras-p2 I levels in the colon. Cancer Detect Prev 2002, 26:78-84.

7. Jiang $Q$ and Ames BN: Gamma-tocopherol, but not alpha-tocopherol, decreases proinflammatory eicosanoids and inflammation damage in rats. FASEB J 2003, $17: 816-822$.

8. Jiang $\mathrm{Q}$, Elson-Schwab I, Courtemanche $C$ and Ames BN: gammatocopherol and its major metabolite, in contrast to alphatocopherol, inhibit cyclooxygenase activity in macrophages and epithelial cells. Proc Natl Acad Sci U S A 2000, 97: I I 494-I I 499.

9. Kliewer SA, Sundseth SS, Jones SA, Brown PJ, Wisely GB and Koble $\mathrm{CS}$ et al.: Fatty acids and eicosanoids regulate gene expression through direct interactions with peroxisome proliferatoractivated receptors alpha and gamma. Proc Natl Acad Sci U S A 1997, 94:43।8-4323.

10. Berger J and Moller DE: THE MECHANISMS OF ACTION OF PPARS. Annu Rev Med 2002, 53:409-435.

II. Murphy GJ and Holder JC: PPAR-gamma agonists: therapeutic role in diabetes, inflammation and cancer. Trends Pharmacol Sci 2000, 2 I:469-474.

12. Tontonoz $P$, Singer $S$, Forman $B$, Sarraf $P$, Fletcher JA and Fletcher $C D$ et al.: Terminal differentiation of human liposarcoma cells induced by ligands for peroxisome proliferator-activated receptor gamma áand the retinoid Xáreceptor. Proceedings of the National Academy of Sciences 1997, 94:237-24I.

13. Elstner E, Muller C, Koshizuka K, Williamson EA, Park D and Asou H et al: Ligands for peroxisome proliferator-activated receptorgamma and retinoic acid receptor inhibit growth and induce apoptosis of human breast cancer cells in vitro and in BNX mice. Proceedings of the National Academy of Sciences 1998, 95:8806-88II. 
14. Kitamura S, Miyazaki Y, Shinomura Y, Kondo S, Kanayama S and Matsuzawa $Y$ : Peroxisome proliferator-activated receptor gamma induces growth arrest and differentiation markers of human colon cancer cells. Jpn J Cancer Res 1999, 90:75-80.

15. Smith MR and Kantoff PW: Peroxisome proliferator-activated receptor gamma (PPargamma) as a novel target for prostate cancer. Invest New Drugs 2002, 20:195-200.

16. Osawa E, Nakajima A, Wada K, Ishimine S, Fujisawa $N$ and Kawamori $\mathrm{T}$ et al:: Peroxisome proliferator-activated receptor gamma ligands suppress colon carcinogenesis induced by azoxymethane in mice. Gastroenterology 2003, 1 24:361-367.

17. Gupta RA and Dubois RN: Controversy: PPARgamma as a target for treatment of colorectal cancer. Am J Physiol Gastrointest Liver Physiol 2002, 283:G266-G269.

18. Thuillier P, Baillie R, Sha $X$ and Clarke SD: Cytosolic and nuclear distribution of PPAR 2 in differentiating 3T3-LI preadipocytes. J Lipid Res 1998, 39:2329-2338.

19. Podda M, Weber C, Traber MG, Milbradt R and Packer L: Sensitive high-performance liquid chromatography techniques for simultaneous determination of tocopherols, tocotrienols, ubiquinols, and ubiquinones in biological samples. Methods Enzymol 1999, 299:330-341.

20. Christen S, Woodall AA, Shigenaga MK, Southwell-Keely PT, Duncan $\mathrm{MW}$ and Ames BN: gamma-tocopherol traps mutagenic electrophiles such as $\mathrm{NO}(X)$ and complements alpha-tocopherol: physiological implications. Proc Natl Acad Sci U S A 1997. 94:3217-3222.

21. Gupta RA and DuBois R: Translational studies on Cox-2 inhibitors in the prevention and treatment of colon cancer. Ann $\mathrm{N}$ Y Acad Sci 2000, 91 10:196-206.

22. Krishnan K, Ruffin MT4, Normolle D, Shureiqui I, Burney K and Bailey $\mathrm{J}$ et al.: Colonic mucosal prostaglandin E2 and cyclooxygenase expression before and after low aspirin doses in subjects at high risk or at normal risk for colorectal cancer. Cancer Epidemiol Biomarkers Prev 200I, 1 0:447-453.

23. Cooney RV, Harwood PJ, Franke AA, Narala K, Sundstrom AK and Berggren $\mathrm{PO}$ et al:: Products of gamma-tocopherol reaction with NO2 and their formation in rat insulinoma (RINm5F) cells. Free Radic Biol Med 1995, 19:259-269.

24. Bittrich H, Matzig AK, Kraker I and Appel KE: NO2-induced DNA single strand breaks are inhibited by antioxidative vitamins in V79 cells. Chem Biol Interact 1993, 86:199-2II.

25. Sugiyama $\mathrm{K}$, Otori $\mathrm{K}$ and Esumi $\mathrm{H}$ : Neoplastic transformation of rat colon epithelial cells by expression of activated human $\mathrm{K}$ ras. Jpn I Cancer Res 1998, 89:615-625.

26. Gysin R, Azzi A and Visarius T: \{gamma\}-Tocopherol inhibits human cancer cell cycle progression and cell proliferation by down-regulation of cyclins. FASEB / 2002, 16: 1952-1954.

27. Murphy G] and Holder JC: PPAR gamma agonists:therapeutic role in diabetes, inflammation, and cancer. Trends in Pharma Sci 2000, $21: 469-474$

28. Kitamura S, Miyazaki $Y$, Hiraoka S, Nagasawa $Y$, Toyota $M$ and Takakura $R$ et al.: PPARgamma agonists inhibit cell growth and suppress the expression of cyclin DI and EGF-like growth factors in ras-transformed rat intestinal epithelial cells. Int Cancer 200I, 94:335-342.

29. Chang TH and Szabo E: Induction of Differentiation and Apoptosis by Ligands of Peroxisome Proliferator-activated Receptor \{\{gamma\}\} in Non-Small Cell Lung Cancer. Cancer Research 2000, 60:1 I29-1138.

30. Gupta RA, Brockman JA, Sarraf P, Willson TM and DuBois RN.: Target genes of peroxisome proliferator-activated receptor gamma in colorectal cancer cells. Journal of Biological Chemistry 200I, 276:2968I-29687.

31. Gao R, Stone WL, Huang T, Papas AM and Qui M: The uptake of tocopherols by RAW 264.7 macrophages. Nutr J 2002, I:2.

32. Clement $M$ and Bourre JM: Graded dietary levels of RRR- $\gamma$-tocopherol induce a marked increase in concentrations of $\alpha$ - and $\gamma$-tocopherol in nervous tissues, heart and muscle of vitamin E deficient rats. Biochimica et Biophysica Acta 2003, I334: I73-I8I.

33. Brigelius-Flohe $R$ and Traber MG: Vitamin E: function and metabolism. FASEB J 1999, I 3: I | 45- I I 55.

34. Stone $W L$ and Papas AM: Tocopherols, Tocotrienols and Vitamin E. In Lipids for Functional Foods and Nutraceuticals Edited by: Gemstone FD. Bridgwater, England: The Oily Press; 2003:53-72.
35. Park KS, Ciaraldi TP, Lindgren K, Abrams-Carter L, Mudaliar S and Nikoulina SE et al.: Troglitazone effects on gene expression in human skeletal muscle of type II diabetes involve up-regulation of peroxisome proliferator-activated receptor-gamma. J Clin Endocrinol Metab 1998, 83:2830-2835.

36. Davies GF, Khandelwal RL and Roesler WJ: Troglitazone induces expression of PPARgamma in liver. Mol Cell Biol Res Commun 1999, 2:202-208.

37. Davies GF, McFie PJ, Khandelwal RL and Roesler WJ: Unique ability of troglitazone to up-regulate peroxisome proliferator-activated receptor-gamma expression in hepatocytes.J Pharmacol Exp Ther 200I, 300:72-77.

\section{Pre-publication history}

The pre-publication history for this paper can be accessed here:

http://www.biomedcentral.com/1471-2407/3/25/prepub
Publish with Bio Med Central and every scientist can read your work free of charge

"BioMed Central will be the most significant development for disseminating the results of biomedical research in our lifetime. "

Sir Paul Nurse, Cancer Research UK

Your research papers will be:

- available free of charge to the entire biomedical community

- peer reviewed and published immediately upon acceptance

- cited in PubMed and archived on PubMed Central

- yours - you keep the copyright
BioMedcentral 